\title{
Recommended Regulated Non-Quarantine Pests: towards a wider and better application of the international concept in the EPPO region
}

\author{
Camille Picard ${ }^{(1)}$, Colin Jeffries ${ }^{(2)}$, Nicolas Ponserre ${ }^{(3)}$, Hanna Kortemaa ${ }^{(4)}$, Martin Ward ${ }^{(1)}$ \\ (1) European and Mediterranean Plant Protection Organization (EPPO). 21 Boulevard Richard Lenoir, 75011 Paris, France. \\ E-mail: cp@eppo.int \\ (2) Science and Advice for Scottish Agriculture (SASA), Roddinglaw Road, Edinburgh, EH12 9FJ, United Kingdom. \\ ${ }^{(3)}$ Groupement National Interprofessionnel des Semences et plants (GNIS), Service Officiel de Contrôle et de Certification, \\ 44 rue du Louvre, 75001 Paris, France. \\ (4) Finnish Food Safety Authority Evira, Seed Certification Unit, P.O.Box 111, 32201 Loimaa, Finland.
}

Received 4 June 2018, accepted 29 January 2019, available online 5 February 2019.

This article is distributed under the terms and conditions of the CC-BY License (http://creativecommons.org/licenses/by/4.0)

Description of the subject. Measures against regulated non-quarantine pests (RNQPs) aim to prevent an unacceptable economic impact on the intended use of plants for planting by pests that are already present in the area. Therefore unlike quarantine pests, the likelihood of introduction of RNQPs is not a relevant criterion. Although the term RNQP was introduced in the FAO International Plant Protection Convention (IPPC) in 1997, to date, very few countries in the EPPO region have used the RNQP concept explicitly. However, in December 2016, the European Union introduced RNQPs in EU Regulation 2016/2031 on protective measures against pests of plants, in line with international standards, to be implemented by December 2019.

Objectives. EPPO undertook a 2-year project, funded by the European Commission, to develop a methodology to assess whether pests should be RNQPs and apply this methodology to pest/host/intended use combinations obtained from Council Directive 2000/29/EC and EU Marketing Directives on reproductive material.

Method. A methodology allowing a quick risk analysis was developed.

Results. This methodology was applied to approximately 1,400 pest/host/intended use combinations within different sector expert working groups, including 44 combinations for the seed potato (i.e. potato plants for planting) sector. When applied to blackleg disease on seed potatoes, experts recommended the listing of the genera Dickeya and Pectobacterium as RNQPs for the EU and the EPPO region.

Conclusions. This project has produced a harmonized evaluation process and recommendations by experts for several pest/host/intended use combinations (as Dickeya spp. and Pectobacterium spp. for seed potatoes) for regulation as RNQPs throughout the EPPO region. EPPO is now considering whether to endorse these recommendations.

Keywords. EU "Quality Pest Project", Solanum tuberosum, Pectobacterium, seed potatoes, plant certification.

Organismes réglementés non de quarantaine : vers une plus large et meilleure application de ce concept international dans la région OEPP

Description du sujet. Les mesures définies sur les organismes réglementés non de quarantaine (ORNQ) visent à éviter un impact économique inacceptable suite à leur présence sur les végétaux destinés à la plantation et ce, bien que ces organismes nuisibles soient déjà présents dans la zone. Ainsi, contrairement aux organismes de quarantaine, le risque d'introduction des ORNQ n'est pas un critère pertinent. Bien que le terme ORNQ ait été introduit en 1997 dans la Convention Internationale pour la Protection des Végétaux (CIPV), jusqu'à présent très peu de pays de la région OEPP ont utilisé ce concept explicitement. Cependant, en décembre 2016, l'Union européenne a introduit les ORNQ dans le Règlement (UE) 2016/2031 relatif aux mesures de protection contre les organismes nuisibles aux végétaux et ce, en cohérence avec les normes internationales. Ce Règlement sera mis en œuvre d'ici décembre 2019.

Objectifs. L'OEPP s'est engagée dans un projet de deux ans, financé par la Commission européenne, ayant pour objectif le développement d'une méthodologie visant à évaluer si un organisme répond aux critères d'un ORNQ et ensuite, à appliquer cette méthodologie sur des combinaisons d'organismes nuisibles/espèces hôtes/usages provenant de la Directive 2000/29/CE et des Directives UE de commercialisation du matériel de reproduction. 
Méthode. Une méthodologie permettant la réalisation d'une analyse de risque rapide a été développée.

Résultats. Cette méthodologie a été appliquée à environ 1400 combinaisons d'organismes nuisibles/espèces hôtes/usages au sein de différents groupes d'experts sectoriels, dont 44 combinaisons pour le secteur pomme de terre de semence (i.e. plant de pomme de terre). Lorsque ladite méthodologie a été appliquée à la maladie de la jambe noire sur pommes de terre de semence, les experts ont recommandé que les genres Dickeya et Pectobacterium soient listés en tant qu'ORNQ pour l'UE et la région OEPP.

Conclusions. Ce projet a produit un processus d'évaluation harmonisé ainsi que des recommandations d'experts en vue de la réglementation de nombreuses combinaisons d'organismes nuisibles/espèces hôtes/usages (comme Dickeya spp. et Pectobacterium spp. pour la pomme de terre de semence) pour la zone OEPP. L'OEPP envisage actuellement d'adopter ces recommandations.

Mots-clés. Projet UE « Organismes de Qualité », Solanum tuberosum, Pectobacterium, plant de pomme de terre, certification des plantes.

\section{INTRODUCTION}

The "Regulated non-quarantine pest" (RNQP) concept was introduced into the revised text of the FAO International Plant Protection Convention (IPPC), approved in 1997 with the following definition: "non-quarantine pests whose presence in plants for planting affect the intended use of those plants with an economically unacceptable impact and which are therefore regulated within the territory of the importing contracting party" (FAO, 1999). In 2002, the International Standard on Phytosanitary Measures (ISPM) No. 16 "Regulated non-quarantine pests: concept and application" (FAO, 2016a) was adopted, describing the concept of RNQPs and their characteristics. A second international standard, ISPM No. 21 "Pest risk analysis for regulated non-quarantine pests" (FAO, 2016b), was adopted in 2004, describing the process for conducting a risk analysis for RNQPs. To date, only a few countries have used the RNQPconcept explicitly; in the EPPO region these include Azerbaijan, Russia and the Ukraine (EPPO, 2017).

Measures against quarantine pests (exclusion, eradication, containment) aim to prevent unacceptable economic, environmental and social impacts resulting from the introduction and/or spread of these pests. In contrast, the concept of RNQPs is intended to prevent an unacceptable economic impact on the intended use of plants for planting by pests that are already present in the area. Indeed, some RNQPs can cause very high negative impacts on the intended use, even though these pests are native or were introduced into the area a long time ago. In this case, specific risk management measures can be defined to limit infestation by the pest, as for example adherence to tolerances that are checked during inspections of growing crops.

In December 2016, the European Union (EU) introduced the IPPC definitions of quarantine pests and regulated non-quarantine pests in (EU) Regulation 2016/2031 (EU, 2016) on protective measures against pests of plants (hereinafter "the new EU Plant Health Law") to be implemented by December
2019. More specifically, Article 36 of this Regulation defines [European] Union RNQPs as pests with a clear taxonomic identity, present in the EU territory, transmitted mainly through specific plants for planting, whose presence has an unacceptable economic impact as regards to the intended use, and where feasible and effective measures are available to prevent their presence on the plants for planting concerned. Union RNQPs are regulated for introduction into and movement within the EU territory, between professional operators.

For this new EU regulation, and for the benefit of the whole EPPO region, EPPO agreed to undertake a 2-year project, starting in April 2016, on RNQPs: "The EU Quality Pest Project". The objective of this project was to develop a methodology and to apply it to a list of candidate pest/host/intended use combinations in order to propose a list of RNQPs to be regulated under the "new EU Plant Health Law" and for recommendation as RNQPs for the EPPO region. This required an assessment of pests currently listed within the EU Marketing Directives on reproductive material, and some additional pests from Annex IIA2 of EU Council Directive 2000/29/EC (EU, 2000) (and from other Annexes if these pests are present and widespread in the EU) proposed by the Working Group on the Annexes of Council Directive 2000/29/EC Section II $^{1}$ (IIA2 AWG) of the European Commission. In addition, some pests which were not listed in the EU Regulations, but which were suggested by NPPOs or stakeholders as good candidates for the RNQP status, were discussed. Since approximately 1,400 pest/host/intended use combinations were proposed

\footnotetext{
${ }^{1}$ Objective of the Working Group on the Annexes of Council Directive 2000/29/EC - Section II (IIA2 AWG) of the European Commission was to guide the process of risk assessments for a list of relevant harmful organisms and to examine whether it is appropriate for those organisms to be listed under the new "EU Plant Health Law" as [European] Union quarantine pests, protected zone quarantine pests, Union regulated non-quarantine pests or being completly deregulated. The IIA2 AWG was asked to prepare, as appropriate, recommendations of the listing of the harmful organisms concerned to the relevant Standing Committee.
} 
for evaluation, a methodology allowing a quick risk analysis was developed and this is described in detail in Picard et al. (2017). The present article describes how the methodology was applied to blackleg disease on seed potatoes (i.e. potato plants for planting).

\section{MATERIALS AND METHODS}

During the first stage of the Project, the methodology for evaluating the RNQP status of pests was developed within a Horizontal Expert Working Group (HEWG) composed of 19 experts nominated by NPPOs. This group included EU and non-EU experts, in order to develop an understanding of the RNQP concept for the whole EPPO region. The final methodology was endorsed by the EPPO Working Party on Phytosanitary Regulations in June 2017. The EPPO Secretariat also developed two questionnaires, one for NPPOs of the EU and one for EU stakeholders' associations to evaluate entries not precisely defined in the Marketing Directives (e.g. entries corresponding to pests not listed at species level), to gather deregulation proposals, and to propose amendments to the current thresholds/requirements/ measures implemented within those Directives or in Annexes of Council Directive 2000/29/EC.

Due to the very high number of pest/host/ intended use combinations to evaluate (approximately $1,400)$, the method developed was based on a quick categorisation process using a decision tree (Figure 1) with qualification (see question on PM $4^{2}$ Standards) and elimination questions (on taxonomy, status in the EU, pathways, economic impact and risk management measures). This method comprised the three following stages:

- initiation stage: listing and naming of candidate pests and host plants to which the methodology will be applied, including confirmation of current taxonomic status;

- categorisation: elimination of those pests which do not fulfil the essential criteria for RNQP status;

- final assessment: recommendation of a list of RNQPs (based on scientific data, literature, and/or practical expertise within Sector Expert Working Groups [SEWGs]).

The full methodology is described in Picard et al. (2017).

During the second stage of the Project, six SEWGs responsible for the practical application of the methodology on specific pest/host/intended use combinations were established: "seed potato", "forestry", "fruit (including hops) and vine",

${ }^{2}$ Standards for the production of healthy plants for planting, https:// gd.eppo.int/standards/PM4/, (2019-01-28). "agricultural species", "vegetable" and "ornamental". Because EPPO has an existing Expert Panel covering quarantine pest risks for potato (Panel on Phytosanitary Measures for Potato), in which there was expertise to provide advice also on the RNQP status, the seed potato SEWG comprised three panel members and seven additional experts nominated by their NPPOs, including two experts from the HEWG to ensure consistency. Experts from outside the EU also participated in this SEWG. The seed potato SEWG applied the methodology on 44 pest/host combinations, including blackleg disease during a 2-day meeting. Results of the evaluation of blackleg disease of seed potatoes are presented in this paper. Blackleg disease was 1 of the 13 candidates used by the HEWG to validate the RNQP methodology.

Draft recommendations were circulated to NPPOs and EU Stakeholders in October 2017. NPPOs and EU Stakeholders associations were asked to provide additional data (scientific data or practical experience) for a possible revision of these draft recommendations during a final expert working group meeting organized in December 2017.

\section{RESULTS}

The RNQP status of the causal agents of blackleg was analysed (Figure 2), by definition of RNQPs, on plants for planting, which excludes ware potatoes. Seed potato production is based on vegetative multiplication of potato tubers over several generations. Current EU Regulations on seed potatoes either refer to blackleg symptoms (EU, 2002; EU, 2014a; EU, 2014b) or to Pectobacterium spp. and Dickeya spp. (EU, 2014b). Also EU Regulations refer to rot symptoms on tubers (EU, 2002; EU, 2014a; EU, 2014b) and that Pectobacterium and Dickeya are also known to cause wet [soft] rot symptoms (Czajkowski et al., 2011). In the EU regulation, Pre-basic material must be free from symptoms of blackleg and must derive from mother plants which are free from Pectobacterium spp. and Dickeya spp. (EU, 2014b), but a tolerance of $1 \%$ and $4 \%$ of blackleg symptoms is permitted on growing plants entered for certification as Basic and Certified seed potatoes, respectively. Additional requirements apply on tuber seed lots as a percentage by mass for rots, other than ring rot or brown rot: $0.2 \%$ for Prebasic and $0.5 \%$ for Basic and Certified categories, of which $0.2 \%$ is specifically for wet rot symptoms.

\subsection{Qualification question based on EPPO PM4 Standards}

EPPO PM 4 "Standards Schemes for the Production of Healthy Plants for Planting" are intended to be used 


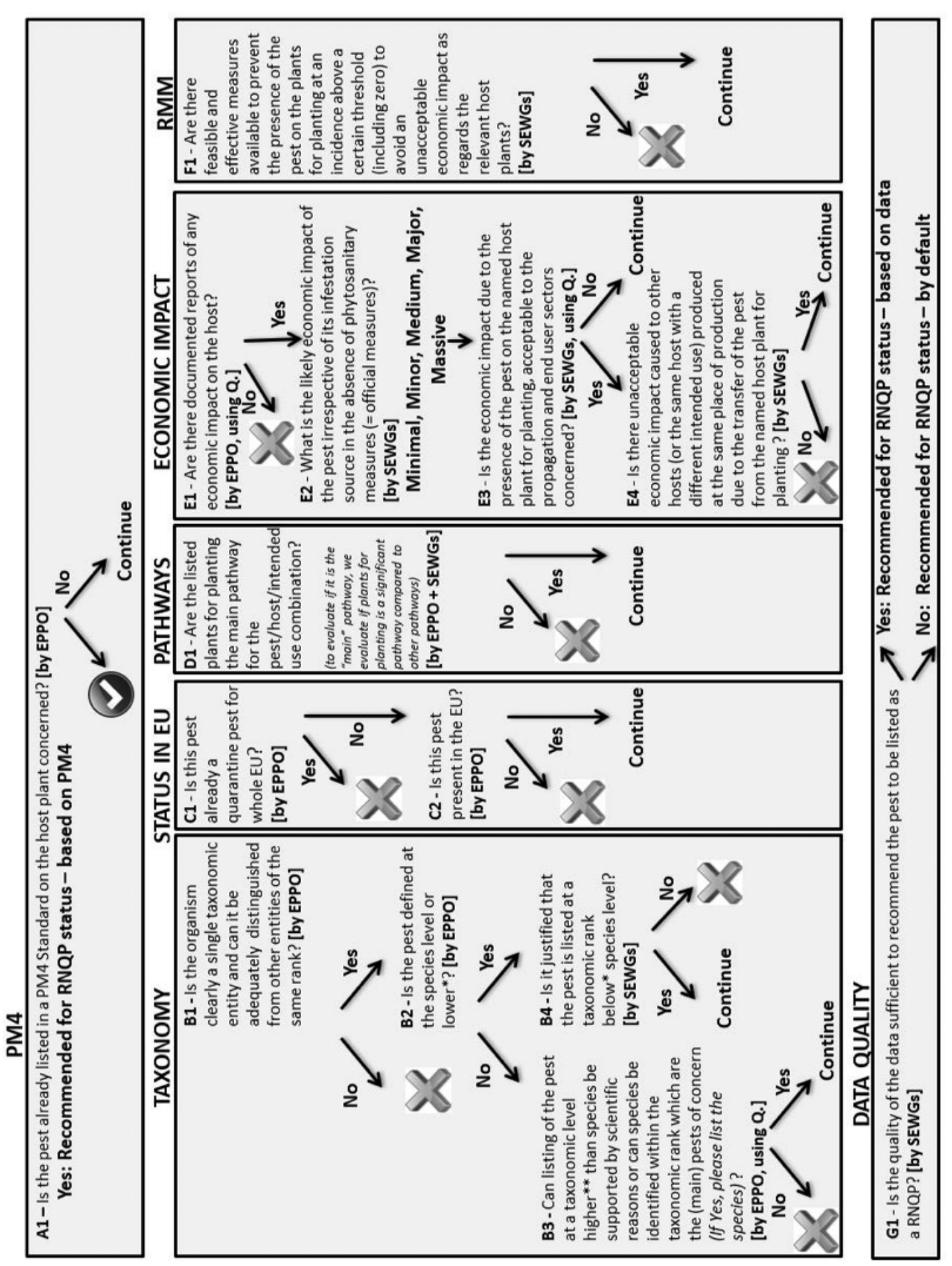

$\ddot{\circ}$ 到

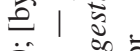

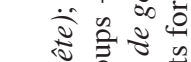

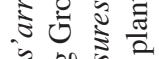

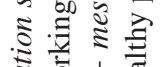
छ (5) 在范

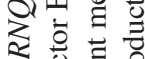
造 క

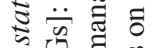

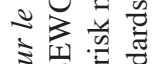

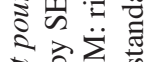
홀 중요 ธิ ำ ङ 을 $\because$ 范

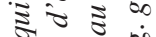
$\approx$ कृ ₹थ

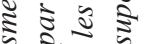
डิ

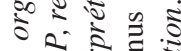

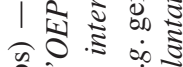
ôे 10 के क क

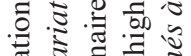

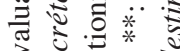
ट ๘ $\approx \approx$ ज्ञ

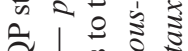

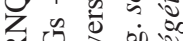
年 च ใด 娄 3 J 원요 ปे 흫ํำ 문 एँ

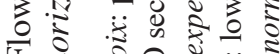
I $50 \div$ ن

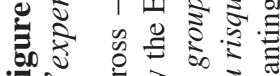

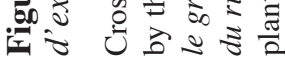



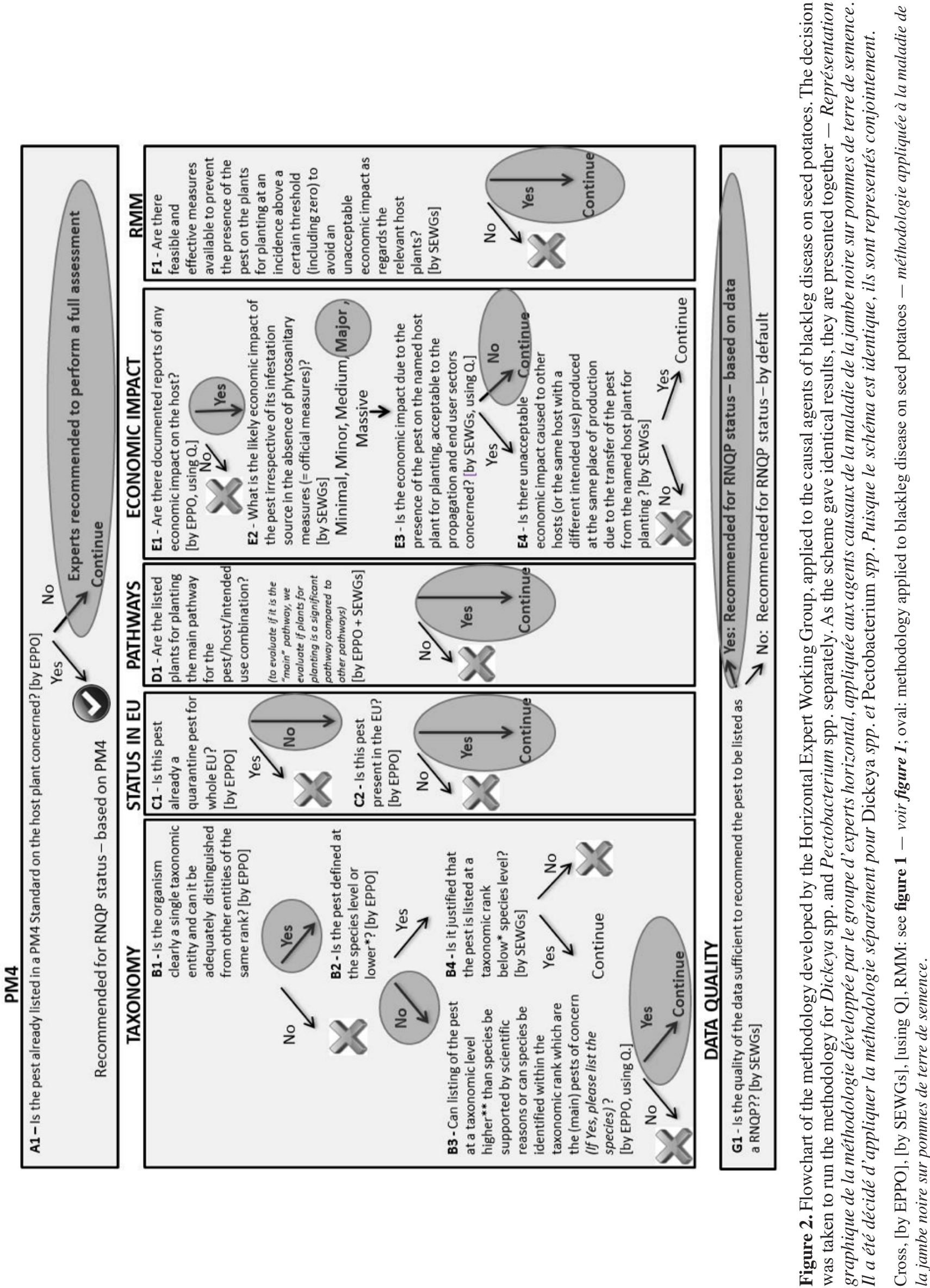
by NPPOs or equivalent authorities, in their capacity as bodies responsible for the design of systems for production of healthy plants for planting, for the inspection of such plants proposed for phytosanitary certification, and for the issue of appropriate certificates. According to the methodology question A1, if a pest is already listed in an EPPO PM4 Standard on the concerned host, it is "by default" considered to qualify as a RNQP. The main justification being that, following peer reviews from experts, there had been agreement at the EPPO level that this pest was relevant for certification. Although no further information will be sought for these pests, the categorisations will be reviewed by the SEWG and further evaluation may be conducted, especially when pests are transmitted by vectors or/and coming from the IIA2 AWG.

EPPO Standard PM 4/28 (1) "Certification scheme for seed potatoes" (EPPO, 1999) was first approved in September 1999 and complemented the UNECE Standard on the production and marketing of seed potatoes adopted in 1963. The requirements for the certification of Pre-basic, Basic and Certified category seed potatoes were aligned, as far as possible, with those of the UNECE Standard, which has been updated several times ever since (UNECE, 2016).

At the time of the writing of these Standards, some of the known species causing blackleg symptoms were considered to belong to the genus Erwinia. Thus, in EPPO PM 4/28 (1), blackleg was associated with Erwinia spp. and considered under wet rot symptoms when dealing with "tuber diseases and defects". In the UNECE Standard (UNECE, 2016), blackleg is currently defined as the "Commonly used name of a bacterial disease of potatoes, generally caused by Pectobacterium atrosepticum (syn. Erwinia carotovora subsp. atroseptica). Similar symptoms may, however, be caused by Pectobacterium carotovorum (formerly E. carotovora subsp. carotovora) and Dickeya spp. (syn. Erwinia chrysanthemi)". According to the methodology developed for the RNQP Project, this pest/host/intended use combination could directly qualify for the RNQP status based on its listing in EPPO PM 4/28 (1).

However, in view of the complexity of blackleg, and because it is currently also listed at the EU level, based on symptoms, experts did not directly qualify it using the qualification question $\mathrm{A} 1$, and instead recommended applying a full assessment for this pest/ host/intended use combination.

\subsection{Taxonomy and level of listing}

According to ISPM 21, the "identity of the pest" and the "taxonomic listing of hosts" should be generally at the species level but if a higher or lower taxonomic level is used this should be supported by a scientifically sound rationale. Various Pectobacterium and Dickeya species or subspecies are reported to cause blackleg symptoms on potatoes in the field as well as rots on tubers. More species associated with tuber rots have been identified and some of them are not known to present symptoms on stems. Anyway, the disease symptoms visible in the field or on tubers cannot be distinguished between the different Dickeya spp. and Pectobacterium spp. In Europe, historically blackleg symptoms on potato stems were associated with Erwinia carotovora subsp. atroseptica (now Pectobacterium atrosepticum). However, more recent studies have shown that Pectobacterium carotovorum subsp. carotovorum (formerly Erwinia carotovora subsp. carotovora), Pectobacterium carotovorum subsp. brasiliense, Pectobacterium parmentieri (= Pectobacterium wasabiae [Khayi et al., 2016; Suarez et al., 2017]) were also responsible for such symptoms (Czajkowski et al., 2015; Euphresco, 2015; Khayi et al., 2016). Since the year 2000, potato losses caused by Dickeya spp. (formerly Erwinia chrysanthemi) have increased significantly and although, mainly associated with $D$. dianthicola and D. solani, other Dickeya spp., $D$. chrysanthemi, D. dadantii, and D. zeae, may also cause blackleg symptoms on seed potatoes in the field (Toth et al., 2011; Czajkowski et al., 2015), and potato is also a host for D. paradisiaca (Toth et al., 2011). Moreover, in the future, new species of Dickeya or Pectobacterium infecting potato coming from other host species may be found, in particular, adapting to current and future climatic conditions (Toth et al., 2011).

In the replies to the RNQP questionnaire, four countries and two EU Stakeholders associations suggested keeping Dickeya and Pectobacterium listed at the genus level. They argued that blackleg symptoms are the result of a bacterial species complex causing similar damage and that the work on species identification is still in progress, and that identification at genus level is the only economical and practical means to certify large amounts of seed potato material.

Because of the diversity of the bacterial species or subspecies involved, for which the studies on species characterisation are still in progress, experts concluded that listing of Dickeya and Pectobacterium at the genus level was appropriate, and that the risk management measures should continue to be based on tested mother plants and on symptoms detected by visual inspection of field crops and tubers in store. Importantly this strategy would not add an extra burden in terms of testing in the seed certification schemes and remains the best practical and reasonable way to manage bacteria whose development depends primarily on environmental and soil conditions. Evaluation of the RNQP status continued on Dickeya and Pectobacterium. 


\subsection{Status (including presence) in the $\mathbf{E U}$}

According to the methodology developed (Picard et al., 2017), a pest cannot be recommended for listing as a RNQP if it is already regulated as a quarantine pest for the whole assessment area, in this case the EU. Moreover, a RNQP should already be present in the assessment area.

In the EU, quarantine pests are currently listed in the annexes of Council Directive 2000/29/EC (which will be repealed in December 2019 by the new "EU Plant Health Law") as well as in EU emergency measures. Pectobacterium and Dickeya are neither listed at the genus level in Council Directive 2000/29/EC nor in EU emergency measures. Therefore, these genera were not considered as being quarantine pests for the whole EU.

Remark: Dickeya dianthicola is listed as E. chrysanthemi pv. dianthicola in Annex II Part A Section 2 of Council Directive 2000/29/EC on Dianthus plants for planting, other than seeds. However, although this pest was no longer considered as a candidate for quarantine status by the IIA2 AWG, the European Commission submitted this pest/host/ intended use combination to the Project for analysis of its RNQP status. It was discussed by the ornamental SEWG who did not recommend it as RNQP on Dianthus plants because there were no recent reports of high negative commercial impact in the EU on this host thus indicating that its importance for Dianthus in the EU has now decreased.

Many studies have shown the diversity and the presence of the causal agents of blackleg disease, in every potato producing areas of the EU. However, the work on species characterisation is still in progress and with the development of new genomic tools, the knowledge on the distribution is evolving. Pectobacterium atrosepticum is the main causal agent of blackleg in temperate regions (Euphresco, 2015; CABI, 2016a). Pectobacterium carotovorum subsp. carotovorum is widespread (CABI, 2016b), has a broad host range worldwide and is especially known to cause soft rot on potato. Pectobacterium wasabiae strains, recently reclassified as $P$. parmentieri (Khayi et al., 2016), have been reported mainly in Northwestern countries (Khayi et al., 2016; Suarez et al., 2017; Zoledowska et al., 2018) but the distribution could have been underestimated as suggested by the recent report in Spain (Suárez et al., 2017). Pectobacterium carotovorum subsp. brasiliense is emerging in Western Europe and has been found in France, The Netherlands, Switzerland and the UK (Nunes Leite et al., 2014; de Werra et al., 2015; Euphresco, 2015).

Dickeya spp. are known to affect a number of host species in different temperature zones. Many EU countries have reported the presence of
D. chrysanthemi, formerly called E.chrysanthemi, on ornamentals (EPPO, 2018a). However, the recent reclassification into six species and progress in identification have shown that most of the disease reports on potato in Europe, identified previously as E. chrysanthemi, correspond to the two predominant bacterial potato pathogens in the genus Dickeya which are $D$. dianthicola and more recently $D$. solani. They have been identified in several EU countries (Euphresco, 2015; CABI, 2018; EPPO, 2018b; Toth et al., 2011). Dickeya dadantii is reported in Germany (but this requires further investigation, since this would be the first report of this species on potato in Europe (Toth et al., 2011)). Distinct genotypes of Dickeya zeae have also been isolated from river water in the UK, but have not yet been found on potato in Europe (Toth et al., 2011).

It was concluded that Dickeya spp. and Pectobacterium spp. are not regulated as quarantine pests in the EU. Although the data collected on the presence of these pests in the EU are not exhaustive according to the methodology, they can show a wide distribution of many different species in the potato producing areas of the region and a full bibliography on the repartition of the different species and subspecies in the EU is not necessary.

\subsection{Pathways}

When developing the methodology, experts agreed that the relative importance of plants for planting as a pathway should only be considered in relation to areas where the pest is present, not for movement into areas which are free from the pest. Indeed, many pests may be introduced to a new area by plants for planting (EPPO, 2012).

Pectobacterium spp. and Dickeya spp. can infect many different host species, including banana, Chrysanthemum spp., Dianthus spp., maize, potato and tomato (Toth et al., 2011). On potato they can be carried on the tuber surface and in lenticels but are also found in the tuber vascular system.

In Europe, there is little or no correlation between Dickeya spp. isolated from river water and those found on potato. In Australia, however, irrigation water was found to be the likely source of infection of potatoes. Dickeya spp. survive in soil for a maximum of a few weeks but their persistence for longer periods in association with crop residues in soil cannot be excluded (Toth et al., 2011).

Although disease expression in the progeny crop is not always directly related to either the growing crop inspection results or bacterial loading in mother tubers because of the influence of the environmental and agronomic factors (UNECE, 2018), experts concluded that, in European conditions, the spread 
of Dickeya spp. and Pectobacterium spp. in seed potato fields takes place mainly via specific plants for planting (latently infected seed tubers), rather than via natural spread or via movement of plant products or other objects. Therefore, plants for planting are a significant pathway compared to other pathways and evaluation was continued.

\subsection{Economic impact}

Economic impact is an important criterion in the evaluation of RNQP status. For Dickeya spp. and Pectobacterium spp., lots of data on the economic impact are available.

Inoculation with $P$. carotovorum subsp. brasiliense and $P$. atrosepticum resulted in high disease incidences (75-95\%). Inoculation with D. solani and P. wasabiae led to disease incidences between 5\% and 25\% (WUR: Euphresco, 2015). In Israel, potato yield reductions up to $30 \%$ have been recorded because of $D$. solani infection across a wide range of commercially produced cultivars and in limited studies yield reductions of up to $50 \%$ from individual plants have been recorded in Finland (CABI, 2018). However, the incidence of the different species and subspecies varied from year to year (FN3PT-RD3PT: Euphresco, 2015). Most direct losses to potato production in Europe caused by Dickeya spp. occur as a result of downgrading or rejection of potatoes during seed tuber certification (Toth et al., 2011). Modelling has shown that blackleg disease is likely to increase in Europe with climate change (JHI: Euphresco, 2015). Strict tolerances in The Netherlands have led to increased direct losses of up to $€ 30 \mathrm{M}$ annually because of downgrading and rejection of seed tuber stocks caused by blackleg. Since it is not possible to differentiate between losses caused by Pectobacterium and Dickeya (Toth et al., 2011) because disease symptoms are indistinguishable, economic impact was evaluated together for all bacteria of the blackleg complex. Experts of the SEWG concluded that the resulting economic impact was major and not acceptable when present on the plants for planting over a certain threshold.

\subsection{Risk management measures}

Experts considered that current risk management measures for the certification of marketed seed potatoes in the EU through use of tolerance levels were effective against blackleg disease caused by Dickeya spp. and Pectobacterium spp. Therefore, they did not recommend any change in the risk management measures and disease thresholds defined in the EU marketing directives for seed potatoes (EU, 2002; EU, 2014a; EU 2014b).

\subsection{Quality data and conclusion of the evaluation}

A final question deals with the data quality. Experts concluded that quality of the data was sufficient to recommend the listing of Pectobacterium spp. and Dickeya spp., at the genus level, as RNQPs for the EU. Furthermore, these recommendations were submitted to the EPPO Working Party on Phytosanitary Regulations in June 2018 to seek their endorsement for the EPPO region.

\section{DISCUSSION}

The present evaluation of the RNQP status of causal agents of blackleg disease only focused on seed potatoes (potato plants for planting, excluding true potato seeds). The marketing of true potato seeds (i.e. potatoes propagated by seeds in the botanical sense) is currently not regulated under EU legislation, although a temporary experiment to market tubers for planting derived from true potato seeds has been approved (EU, 2017). Claimed advantages over traditional clonal propagation include permitting the quickerdevelopment of new varieties with combinations of useful traits and shortening the number of field generations, thus reducing the accumulation of potato pests. However, experts considered that it would be better to focus on material that is currently marketed under a permanent legal basis in the EU (i.e. plants for planting, excluding true seeds). Therefore, this evaluation would need to be completed by an evaluation for true potato seeds if marketed, in the future, under a permanent legal basis in the EU.

If the decision by the seed potato SEWG would have been to list all the bacterial species or subspecies involved in blackleg disease and evaluate the RNQP status for each of these taxa, more uncertainty would have been faced in the evaluation (e.g. in relation to the recent improvement of detection methods and therefore to the lack of data about the repartition, or to the economic impact for each of these taxa). Moreover, some of these taxa could have been considered as not fulfilling the RNQP status. However, as long as the risk management measures remain based on symptoms, as is currently the case for EU for Pre-basic, Basic and Certified material (but not for mother plants which are usually tested), listing a restricted number of taxa would not change the current situation. Indeed, the listing of some of these taxa as RNQPs, based on visual examination, would indirectly support measures which cover other taxa not qualified as RNQPs and presenting similar symptoms.

In addition, because of the apparently limited distribution of some of these taxa, this could have posed the question whether these taxa should have quarantine 
status in countries where they are absent. However, the project itself did not make any recommendation on changes in quarantine status, only on suitability for RNQP status.

Because of time constraints, evaluation of economic impact was mostly based on a qualitative approach, focusing on collating information available from NPPOs and stakeholders, supplemented by a literature search approach. These data were reviewed and refined by experts before they made an assessment of the economic impact on a five-level scale adapted from PM 5/3 (5) (EPPO, 2011; and discussed in Bremmer et al., 2012), and reached a conclusion on the acceptability of this impact. Therefore, although this work could have been completed by a thorough quantitative analysis of the economic impact, experts considered that this would probably not have changed the conclusions reached during the expert working group.

\section{CONCLUSIONS}

The RNQP project was carried out, from April 2016 to April 2018 on approximately 1,400 pest/host/ intended use combinations. Sharing the methodology (Picard et al., 2017), with an example of its practical application on blackleg disease on seed potatoes, should help harmonize the process of RNQP evaluation in the EPPO region. This methodology was applied to 44 pest/host combinations for the seed potato sector. In addition to blackleg, the suitability for RNQP listing of pests and diseases such as common scab, black scurf, powdery scab, silver scurf, different rots, various viruses (including Tomato spotted wilt virus), Potato spindle tuber viroid, Helicoverpa armigera, 'Candidatus Phytoplasma solani', 'Candidatus Liberibacter solanacearum' and Ditylenchus destructor, were also assessed. All the recommendations of the RNQP Project are now available to EPPO member countries and stakeholders at the following address https://rnqp.eppo.int/. This should also contribute to the harmonization of the list of RNQPs in the EPPO region.

\section{Acknowledgements}

This article was written in the context of a project funded by the European Commission, DG Health and Food Safety under the contract SANTE/2016/G1/SI2.726941: Review of the EU regulated quality pests and development of risk assessment for a list of Union Quality Pests to be established by the European Commission in the frame of the new EU Regulation on protective measures against pests of plants ("EU quality pest project"). The authors would like to thank all participants of the seed potato SEWG in addition to those who participated directly in the writing of this article (Mr Albakri [JO], Mr Alonso Arce [ES], Mr Soellinger [AT] and Mr Waterink [NL]).

\section{Bibliography}

Bremmer J. et al., 2012. Improvements to the economic impact assessment section of the EPPO PRA scheme. Bull. OEPP/EPPO Bull., 42, 13-20.

CABI, 2016a. Datasheets Pectobacterium atrosepticum (potato blackleg disease). Invasive species compendium. Wallingford, UK: CABI.

CABI, 2016b. Datasheets Pectobacterium carotovorum subsp. carotovorum (bacterial root rot of sweet potato). Invasive species compendium. Wallingford, UK: CABI.

CABI, 2018. Datasheets Dickeya solani (blackleg disease of potato). Invasive species compendium. Wallingford, UK: CABI.

Czajkowski R. et al., 2011. Control of blackleg and tuber soft rot of potato caused by Pectobacterium and Dickeya species: a review. Plant Pathol., 60, 999-1013.

Czajkowski R. et al., 2015. Detection, identification and differentiation of Pectobacterium and Dickeya species causing potato blackleg and tuber soft rot: a review. Ann. Appl. Biol., 166, 18-38.

de Werra P., Bussereau F., Keiser A. \& Ziegler D., 2015. First report of potato blackleg caused by Pectobacterium carotovorum subsp. brasiliense in Switzerland. Plant Dis., 99, 551-552.

EPPO, 1999. EPPO Standards PM 4/28 (1) Certification schemes. Seed potatoes. Bull. OEPP/EPPO Bull., 29, 253-267.

EPPO, 2011. EPPO Standards PM 5/3 (5). Guidelines on pest risk analysis. Decision -support scheme for quarantine pests, https://gd.eppo.int/download/standard/117/PRA_ scheme_2011.doc,(2018-04-01).

EPPO, 2012. EPPO technical document no. 1061: EPPO study on the risk of imports of plants for planting, https:// www.eppo.int/media/uploaded_images/RESOURCES/ eppo_publications/td_1061_plants_for_planting.pdf, (2019-02-04).

EPPO, 2017. EPPO Global Database, https://gd.eppo.int, (2017-12-01).

EPPO, 2018a. EPPO Global Database. Distribution of Dickeya chrysanthemi, https://gd.eppo.int/taxon/ ERWICH/distribution, (2018-04-01).

EPPO, 2018b. EPPO Global Database. Distribution of Dickeya dianthicola, https://gd.eppo.int/taxon/ ERWICD/distribution, (2018-04-01).

EU, 2000. Council Directive 2000/29/EC of 8 May 2000 on protective measures against the introduction into the Community of organisms harmful to plants or plant products and against their spread within the Community. Off. J. Eur. Union, L169 (10.07.2000, consolidated version of 30.06 .2014$), 1-181$. 
EU, 2002. Council Directive 2002/56/EC of 13 June 2002 (lastly amended 3 March 2016) on the marketing of seed potatoes. Off. J. Eur. Union, L193/60 (20.7.2002).

EU, 2014a. Commission implementing Directive 2014/20/ UE of 6 February 2014 determining minimum conditions and Union grades for pre-basic seed potatoes. Off. J. Eur. Union, L38/32 (7.2.2014).

EU, 2014b. Commission implementing Directive 2014/21/ UE of 6 February 2014 determining Union grades of basic and certified seed potatoes, and the conditions and designations applicable to such grades. Off. J. Eur. Union, L38/32 (7.2.2014).

EU, 2016. Regulation of the European Parliament and the Council on protective measures against pests of plants. Off. J.Eur. Union, L317/4 (23.11.2016), http://eur-lex .europa. eu/legal-content/EN/TXT/?uri=CELEX:32016R2031, (2019-01-25).

EU, 2017. Commission implementing Decision 2017/547 of 21 March 2017 on the organisation of a temporary experiment under Council Directive 2002/56/EC as regards seed potato tubers derived from true potato seed. Off. J. Eur. Union, L78/65 (23.03.2017).

Euphresco, 2015. Assessment of Dickeya sp. and Pectobacterium spp. on potatoes and ornamentals (Dickeya). Final report, https://www.euphresco.net/ media/project_reports/dickeya_final_report.pdf, (201803-20).

FAO, 1999. International Plant Protection Convention (new revised text approved by the FAO Conference at its $29^{\text {th }}$ Session - November 1997). Roma: FAO.

FAO, 2016a. International Plant Protection Convention (IPPC). International standards for phytosanitary measures (ISPM) No. 16, Regulated Non-Quarantine Pests: concept and application. Roma: FAO.

FAO, 2016b. International Plant Protection Convention (IPPC). International standards for phytosanitary measures (ISPM) No. 21, Pest risk analysis for regulated non-quarantine pests. Roma: FAO.
Khayi S. et al., 2016. Transfer of the potato plant isolates of Pectobacterium wasabiae to Pectobacterium parmentieri sp. nov. Int. J. Syst. Evol. Microbiol., 66, 5379-5383.

Nunes Leite L. et al., 2014. First report of potato blackleg caused by Pectobacterium carotovorum subsp. brasiliensis in the Netherlands. New Dis. Rep., 29, 24.

Picard et al., 2017. A methodology for preparing a list of recommended regulated non-quarantine pests (RNQPs). Bull. OEPP/EPPO Bull., 47, 551-558.

Suarez M.B. et al., 2017. Disease notes. Pectobacterium parmentieri causing soft rot on potato tubers in Southern Europe. Plant Dis., 101, 1029.

Toth I.K. et al., 2011. Dickeya species: an emerging problem for potato production in Europe. Plant Pathol., 60, 385399.

UNECE, 2016. Standard S1 concerning the marketing and commercial quality control of seed potatoes. Revised standard for seed potatoes recommended by the working party on standardization of perishable produce and quality development of the United Nations Economic Commission for Europe. Geneva, Switzerland: United Nations, https://www.unece.org/trade/agr/standard/ potatoes/pot_e.html,(2018-03-20).

UNECE, 2018. The position of the specialized section on standardization of seed potatoes on blackleg of seed potatoes. Geneva, Switzerland: United Nations Economic Commission for Europe, https:/www.unece. org/trade/agr/standard/potatoes/pot_e.html, (2018-0412).

Zoledowska S. et al., 2018. Population structure and biodiversity of Pectobacterium parmentieri isolated from potato fields in temperate climate. Plant Dis., 102, 154-164.

(31 ref.) 